\title{
Study on Livelihood Vulnerability and Adaptation Strategies of Farmers in Areas Threatened by Different Disaster Types under Climate Change
}

\author{
Xue Yang ${ }^{1}$, Shili Guo ${ }^{2}$, Xin Deng ${ }^{3}$, Wei Wang ${ }^{1}$ (D) and Dingde $\mathrm{Xu}^{4, *}$ \\ 1 College of Management, Sichuan Agricultural University, Chengdu 611130, China; \\ yangxue@stu.sicau.edu.cn (X.Y.); wangwei@sicau.edu.cn (W.W.) \\ 2 China Western Economic Research Center, Southwestern University of Finance and Economics, \\ Chengdu 610074, China; guoshili@swufe.edu.cn \\ 3 College of Economics, Sichuan Agricultural University, Chengdu 611130, China; dengxin@sicau.edu.cn \\ 4 Sichuan Center for Rural Development Research, College of Management, Sichuan Agricultural University, \\ Chengdu 611130, China \\ * Correspondence: dingdexu@sicau.edu.cn; Tel.: +86-13-4085-988-19
}

\section{check for} updates

Citation: Yang, X.; Guo, S.; Deng, X.; Wang, W.; Xu, D. Study on Livelihood Vulnerability and Adaptation Strategies of Farmers in Areas Threatened by Different Disaster Types under Climate Change. Agriculture 2021, 11, 1088. https:// doi.org/10.3390/agriculture11111088

\section{Academic Editors:}

Francesco Caracciolo, Danilo Bertoni and Raffaele Cortignani

Received: 23 September 2021 Accepted: 1 November 2021 Published: 3 November 2021

Publisher's Note: MDPI stays neutral with regard to jurisdictional claims in published maps and institutional affiliations.

Copyright: (c) 2021 by the authors. Licensee MDPI, Basel, Switzerland. This article is an open access article distributed under the terms and conditions of the Creative Commons Attribution (CC BY) license (https:/ / creativecommons.org/licenses/by/ $4.0 /)$.

\begin{abstract}
The intensification of global climate change leads to frequent mountain torrents, landslides, debris flows and other disasters, which seriously threaten the safety of residents' lives and property. However, few studies have compared and analyzed the livelihood vulnerability and adaptation strategies of farmers in different disaster-threatened areas under the background of climate change. Based on survey data of 327 households in the areas threatened by mountain floods, landslides and debris flow in Sichuan Province, this study analyzed the characteristics of livelihood vulnerability and adaptation strategies of households in the areas threatened by different disaster types and constructed multinomial logistic regression models to explore their correlations. The findings show that: (1) The livelihood vulnerability indices of farmers in different hazard types showed different characteristics. Among them, the livelihood vulnerability index of farmers in landslide-threatened zones is the highest, followed by the livelihood vulnerability index of farmers in debris-flow-threatened zones, and finally the livelihood vulnerability index of farmers in flash flood threat zones. At the same time, all three natural hazards show a trend of higher vulnerability in the sensitivity dimension than in the exposure and livelihood resilience dimensions. (2) The nonfarming livelihood strategy is the main livelihood strategy for farmers in different disaster-type-threatened areas. At the same time, the vulnerability of farmers choosing the nonfarming livelihood strategy is much higher than that of farmers choosing the part-time livelihood strategy and pure farming livelihood strategy, and the vulnerability of sensitivity dimension is higher than that of the exposure dimension and livelihood resilience dimension. (3) For farmers in landslide- and debris-flow-threatened areas, livelihood resilience is an important factor affecting their livelihood strategy. There was a positive correlation between livelihood resilience and farmers' choice of pure agricultural livelihood strategies in these two natural-disaster-threatened areas. This study deepens our understanding of the characteristics and relationships of farmers' livelihood vulnerability and adaptation strategies under different disaster types in the context of climate change, and then provides the reference basis for the formulation of livelihood-adaptive capacity promotion-related policy.
\end{abstract}

Keywords: livelihood vulnerability; livelihood strategy; meteorological disaster; China

\section{Introduction}

Due to climate change, the frequency and severity of extreme weather events are expected to increase globally [1]. At the same time, the occurrence of rainstorm, flood and various geological disasters will also increase [2]. According to the report "Human Losses from Disasters 2000-2019" released by the UNDRR in October 2020, the number of 
natural disasters around the world soared from 3656 to 6681 in 2000-2019, and the affected population increased from 3.2 billion to 3.9 billion. Among them, extreme rainfall, due to its short duration and high intensity, easily leads to lead to flash floods, landslides and debris flows, causing huge casualties and property losses [3-5]. According to statistics, in the 21st century, the global economic losses caused by mountain torrents alone have reached USD 46 billion every year [6]. Meanwhile, according to the data of China Climate Bulletin, in 2020 alone, China's meteorological disasters will cause 19.6 million hectares of crop damage and direct economic losses of up to USD 52.89 billion. Among them, Sichuan Province, located in the hinterland of southwest China, has become one of the regions most affected by meteorological disasters in China because of its unique geographical conditions. According to statistics, from 2010 to 2019, the frequency of the occurance of flood and geological disasters caused by heavy rain events in Sichuan mountains is about 74.90\% [7]. The disaster area caused by natural disasters such as flood and geological disasters is as high as 3195.9 thousand hectares, the number of people affected is 179.603 million, and the direct economic loss is USD 46.20 billion [8]. Natural disasters caused by climate change have seriously affected the sustainability of residents' livelihoods [9-15], there is an urgent need to strengthen the research on livelihood vulnerability and livelihood adaptation of residents in natural disaster threatened areas [16].

The article is structured as follows: after the introduction, the second part mainly analyzes the theoretical background of livelihood vulnerability and livelihood strategies, and in the third part, by explaining the analytical framework of the IPCC vulnerability assessment, the corresponding three research hypotheses are proposed through theoretical analysis. The fourth section describes the data and methods used in this study. The fifth part presents the results using descriptive statistical analysis. The sixth part interprets the results of the study by combining them with other academic studies to test the hypotheses. The seventh part presents the corresponding policy recommendations in the context of the findings of the study.

\section{Theoretical Background}

In order to deal with climate change, the world set up the Intergovernmental Panel on Climate Change (IPCC), which is specialized in the research of climate change and its adaptation. Among them, as vulnerability and adaptation are keys in the cycle of disaster coping and disaster-risk reduction for residents now and in the future [17], more and more studies have begun to focus on the livelihood vulnerability of farmers and their livelihood adaptation strategies under the background of climate change [18-20]. Vulnerability refers to the extent to which a system or system components are unable to cope with adverse environmental impacts such as climate change or natural disasters [21], including the three components of exposure, sensitivity and adaptability [22]. It is noted that although there is a long history of vulnerability research in the academic world, there is no uniform measurement method. For example, some studies measure ecosystem vulnerability through species diversity [23-25], some studies measure poverty vulnerability through external shocks and internal treatment [26-28], some studies measure agricultural vulnerability through crop yield, agricultural profitability and regional economic development [29-31], some studies measure resource vulnerability through energy intensity, energy import and energy consumption [32,33]. Although the index systems of various vulnerability assessments are not the same, the assessment methods mostly adopt the method proposed by Adger in 2005, which divides vulnerability into three dimensions of exposure, sensitivity and adaptability. Livelihood vulnerability is taken as a function of exposure and adaptability and is combined with the sensitivity measure of vulnerability [34,35]. Livelihood vulnerability is used to understand the impact of demographic, social and physical factors on vulnerability to climate change and to provide governments with the required vulnerability information [36]. The Livelihood Vulnerability Index is a composite index of all major indicators of livelihood vulnerability [37]. As research has progressed, the IPCC vulnerability-assessment framework has become the primary tool for such research [38]. In 
addition, it is noted that in recent years, academic research on vulnerability has focused on vulnerability assessment regarding a single type of disaster $[35,36,39,40]$ for example, floods [41], droughts [42], earthquakes [43], or extreme weather changes [44-46], and relatively few studies have been conducted on the differences and comparisons between the vulnerability of farmers in different natural-disaster-threatened areas, and relevant research is urgently needed.

In the face of more frequent and serious threats from global climate events, adopting appropriate livelihood strategies is an effective means to improve resilience [47-49]. Livelihood strategies refer to the activities and choices people make to achieve their livelihood goals, including production activities, investment strategies, and reproduction choices [50], especially strengthening the territorial and social responsibility of farmers [51], which can help farmers to proactively cope with disasters and reduce disaster risks [52]. However, according to existing research, in the studies on the driving mechanisms of livelihood strategy selection, scholars mostly pay attention to the correlation between livelihood capital and livelihood strategy of farmers $[53,54]$, and the impact of livelihood risk on livelihood strategy $[55,56]$. Livelihood strategies are key determinants of livelihood vulnerability $[57,58]$, but few studies have focused on the relationship between farmers' livelihood vulnerability and choice of livelihood strategies in areas threatened by different types of natural disasters in the context of climate change. Therefore, research on livelihood strategy from the perspective of vulnerability needs to be further explored.

Based on the background that relatively few studies have made cross-sectional comparisons of different hazards from the perspective of farmers, and relatively few studies have explored the choice of livelihood strategies from the perspective of livelihood vulnerability, this study uses survey data from 327 households in natural-hazard-threatened areas of landslide, debris flow and flood in Sichuan Province, China, integrates the IPCC vulnerability-assessment framework, compares the differences between farmers under the impact of different natural hazards by calculating the livelihood vulnerability index, and constructs an econometric model to explore the relationship between farmers' livelihood vulnerability and their choice of livelihood strategies in different natural-hazard-threatened areas. This study aims to investigate the following two problems:

(1) What are the characteristics and differences of household livelihood vulnerability and livelihood strategy choice in different natural-disaster-threatened areas (landslide, debris flow and flood)?

(2) What is the correlation between household livelihood vulnerability and livelihood strategy choice in different natural-disaster-threatened areas (landslide, debris flow and flood)?

\section{Theoretical Analysis and Research Hypothesis}

In order to answer the above research questions, this paper analyzes the microclimate change vulnerability at the household level and develops and compares it on the basis of different indicators. A large number of studies have shown that climate change has become a major factor affecting agricultural production and farmers' livelihoods [59-61]. For this reason, the IPCC has developed a theoretical analysis framework that combines ecological, biophysical and social vulnerability [62], and has defined vulnerability as the tendency to be adversely affected [63]. Vulnerability includes various concepts and elements, including sensitivity to injury and lack of ability to cope and adapt [64].

Based on this, the vulnerability assessment and analysis framework of IPCC divides vulnerability into three dimensions: exposure, sensitivity and adaptability $[37,65,66]$, and emphasizes helping vulnerable groups to reduce internal and external impact damage to maintain the stability of the group's future development [35]. Among them, exposure refers to the nature and extent of a system's exposure to significant climate change, based primarily on the extent of exposure [63]. Sensitivity refers to the degree to which a system is affected by adverse or beneficial effects of climate change, which may be direct or indirect, such as sensitivity to water, food and health [63]. Livelihood resilience refers to the ability 
of social systems to respond to and recover from disasters, depending primarily on social networks, livelihood strategies and sociodemographic profiles [67]. In the framework of vulnerability-assessment analysis, there is a functional relationship between exposure, sensitivity and livelihood resilience and vulnerability, and potential climate impacts can be reduced through adaptation measures to enhance adaptive capacity [68].

Therefore, taking into account the research objectives and regional realities, this study will use the IPCC's vulnerability-assessment analysis framework and apply the vulnerability index (IPCC-LVI) to explore the influencing factors of livelihood strategies, hoping to provide bases for policy formulation for farmers in different disaster-type regions.

Due to the differences in topography and economic development levels, many farmers have been living in areas threatened by natural disasters for a long time, and some farmers even live in known disaster areas (such as debris flow fans) [69-74]. This means that they are vulnerable to disasters under extreme weather conditions (such as heavy rain) [75]. Among them, developing countries are more vulnerable to natural-disaster shocks due to weak coping strategies and imprecise institutional frameworks [76], especially in mountainous areas where people are chronically affected by poor local socioeconomic development and have increased levels of vulnerability [77]. For different natural disasters, the livelihood vulnerability of farmers in different dimensions will show different characteristics. For example, in landslide- and debris-flow-threatened areas, Peng et al. found that households' exposure dimension and sensitivity dimension showed higher vulnerability, and high vulnerability was accompanied by high sensitivity [78], while Lim et al. found that households' exposure-dimension vulnerability was higher than their sensitivity and adaptability [79]. The exposure dimension at this point reflects the external shocks faced by farm households in the region, mainly relying on landslide shocks, agricultural shocks, and other economic shocks for measurement; the sensitivity dimension aims to reflect the impact of external shocks on farm households, mainly relying on indicators such as consumption, indebtedness, and drinking water for measurement. In flood-threatened areas, Bhattacharjee and Behera found that the vulnerability scores of farmers' exposure and sensitivity were higher than the vulnerability scores of their overall adaptability [38]. Hoq et al. found that the vulnerability of farmers in the exposure dimension was the highest, followed by the sensitivity dimension and the adaptability dimension [80]. Based on this, this research makes the following hypothesis:

Hypothesis 1 (H1). There are significant differences in the livelihood vulnerability dimensions of farmers in different natural-disaster-threatened areas.

Livelihood strategies are the most effective protection against external shocks [81]. Farmers' livelihood strategies will be constantly adjusted with changes in policies and systems, external environment and their own capital. Theoretically, farmers in different natural-disaster-threatened areas will adopt different livelihood strategies according to their social and economic differences. Natural disasters such as landslides, debris flows and floods will not only lead to the decline in income and welfare level of the affected families, but also lead to the widening of the income gap between resident families [82]. In these threatened areas, nonagricultural income is the main part of the overall income of farmers. After the impact of natural disasters, the proportion of farmers taking pure farming (planting) as their main livelihood strategy will significantly decrease, while the proportion having nonfarming (working) as their main livelihood strategy will greatly increase. In general, farm households in developing countries, especially in mountainous areas, are highly dependent on nature [83], and the direct losses from the adverse effects of natural weather hazards on business and industry are much lower than those from agriculture [84]. For farmers in mountainous areas threatened by natural disasters, the stronger their buffer capacity (mainly including livelihood capital) is, the more likely they are to choose a nonagricultural livelihood strategy [67], and the income from nonagricultural production activities is often higher than that from part-time and pure agricultural livelihood strategy [85]. Buffer capacity represents the ability of farmers to use their own 
livelihood capital or resource endowment to cope with external risk disturbances [86]. From the perspective of livelihood capital, the capacity to buffer the ability of farmers to use their own resources and power to withstand livelihood risks is an important measure of livelihood resilience [87]. The more abundant human and financial resources, the more sensitive the farmers are $[78,88]$. Based on this, this study makes the following assumptions:

Hypothesis 2 (H2). There are significant differences in the forms of vulnerability of households with different livelihood strategies in different natural disaster threat areas.

Exposure, sensitivity and adaptability may be significantly related to livelihood strategy. Among them, there is a significant negative correlation between income and adaptability $[38,76]$. Environmental risks that have a large impact (such as geological disasters and extreme weather) will have a huge impact on farmers' assets [89]. At this point, farmers in disaster-threatened areas will take the initiative to engage in nonagricultural production activities to reduce the losses caused by natural disasters [55]. Sensitivity reflects the extent to which the major components of the system are affected by exposure. Generally speaking, the higher the sensitivity, the more threatened the livelihood capital of residents is [36]. When faced with the impact of health and social relationship risks, farmers are more likely to choose off-farm livelihood strategies (such as saving and migrant work) [55]. There was a significant negative correlation between income and the vulnerability index of adaptability dimension. Farmers with strong livelihood resilience tend to have more people, money and material resources, and have a variety of livelihood strategies to choose from [90]. Poudel et al. believe that the farmers that rely only on agriculture for income will be more vulnerable [36]. As long as there is free space for farmers to choose, in order to pursue the maximization of interests, farmers in the threat area will be more inclined to engage in nonagricultural production activities. Based on this, the following hypotheses are made in this study:

Hypothesis 3 (H3). The higher the vulnerability of exposure, sensitivity and livelihood resilience dimensions of farmers in different natural-disaster-threatened zones, the more they tend to be positively associated with the choice of non-farm-based livelihood strategies.

\section{Data and Methods}

\subsection{Data Collection}

The objective of this study is to analyze the characteristics and differences of livelihood vulnerability and livelihood-strategy choice of farmers in different natural-disasterthreatened areas, and to explore the correlation between livelihood vulnerability and livelihood-strategy choice. To achieve this goal, it is necessary to collect data from a primary survey of farmers in different natural-disaster-threatened areas. Referring to the study by $\mathrm{Xu}$ et al. [81], considering the actual situation in Sichuan Province, this study mainly focuses on landslide, debris flow and mountain flood, three kinds of natural disasters closely related to climate change. Questionnaire content involves farmers' livelihood vulnerability (exposure, sensitivity and resilience) and livelihood-strategy choice. In order to ensure the typicality and representativeness of the sample data, the research group adopted the stratified equal-probability random-sampling method to determine the samples. Firstly, 4 districts and counties (Beichuan, Pengzhou, Baoxing and Lushan) were selected as sample counties from 183 districts and counties in Sichuan Province according to the types of natural disasters (Figure 1). After 4 sample counties were determined, 2 sample towns were randomly selected from each sample county based on indicators such as economic development level and disaster threat degree, and finally 8 sample towns were obtained. Then, based on factors such as the regional economic level of the sample township, the distance between the village and the township center, and the degree of disaster, 2 sample villages are randomly selected from each sample township, and 16 sample villages are finally obtained. Then, considering that Chinese village cadres have a better understanding of the local area, according to the roster provided by village cadres, 20-23 households were randomly selected from each sample village as sample households. Finally, the research 
team obtained 327 valid questionnaires from farmers in 4 districts, 8 towns and 16 villages. Among them, the number of households corresponding to landslide, debris flow and mountain flood, respectively is 189,99 and 39 .
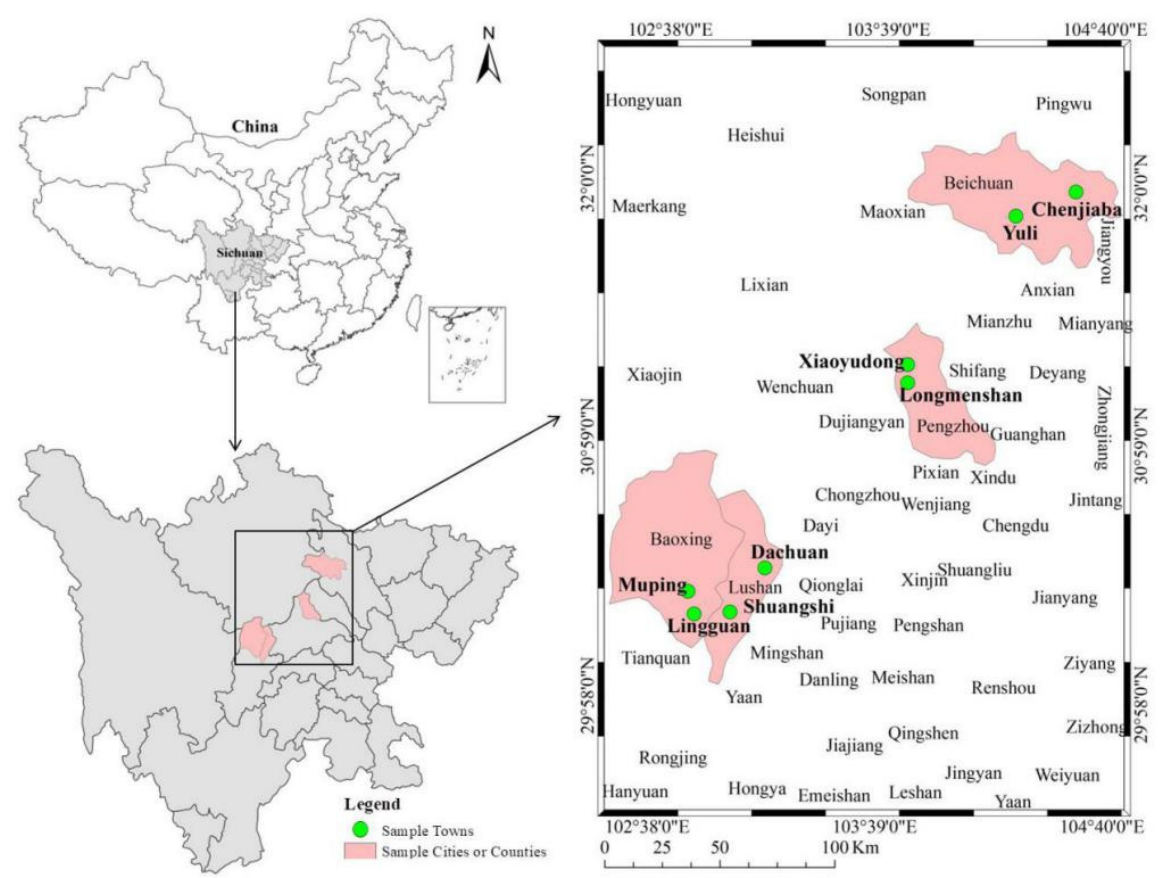

Figure 1. Location map of sample counties and towns. (Source: National Natural Science Foundation of China project, 2019).

Before the survey, the group initially estimated that each village would collect data on 24 farm households. In the actual survey process, with the consent of the interviewees, 13 systematically trained investigators under the leadership of village cadres adopted a one-to-one household research approach, with each questionnaire taking 1-1.5 h, and only 20-23 households being collected in each village due to limited funds, scattered farmers in mountainous areas and the increasing cost of survey time. However, our surveyed sample of farm households was generated through a random number table and there is a high degree of homogeneity in rural areas of China. Therefore, our sample is still random and highly representative.

\subsection{Index Selection}

Regarding the measurement of livelihood vulnerability, this study refers to the theoretical analysis framework of the IPCC and divides it into the three dimensions of exposure, sensitivity and livelihood resilience, with specific measures for each dimension referring to Alam; Hahn et al.; Malakar et al.; Pandey et al.; Peng et al.; Sarker et al.; Sujakhu et al.; Zhao et al. and other studies, and designs the indicator system with the actual study area (Table 1) [35,78,91-96].

For the exposure dimension, in order to fully portray the vulnerable environment faced by farmers, this paper not only selects the exposure dimension vulnerability index by climate change related disasters-landslides, debris flows and floods, including indicators such as the number of times farmers experienced disasters, the damage and whether they received pre-disaster warnings in advance, but also selects indicators directly related to climate change, such as climate change concerns and soil erosion. 
Table 1. Major dimensions and subdimensions comprising the IPCC-LVI developed for flood- and geological hazard-flowthreatened area. (Source: the author, 2021).

\begin{tabular}{|c|c|c|c|c|}
\hline $\begin{array}{l}\text { IPCC } \\
\text { Contributing } \\
\text { Factor }\end{array}$ & $\begin{array}{c}\text { Major } \\
\text { Dimensions }\end{array}$ & Subdimensions & Explanation & Source \\
\hline \multirow{6}{*}{ Exposure } & \multirow{3}{*}{ Natural disaster } & $\begin{array}{l}\text { Landslide, debris flow } \\
\text { or flood shock }\end{array}$ & $\begin{array}{l}\text { The number of landslides, debris flow or } \\
\text { flood shock }\end{array}$ & $\begin{array}{c}\text { Developed for the purposes } \\
\text { of this questionnaire }\end{array}$ \\
\hline & & Injury & $\begin{array}{l}\text { Whether the family was injured as a } \\
\text { result of the disaster (landslide, debris } \\
\text { flow or flood })(0=\text { no, } 1=\text { yes })\end{array}$ & [91] \\
\hline & & $\begin{array}{c}\text { Circumstances of households } \\
\text { that do not receive a warning } \\
\text { before a natural disaster } \\
\text { (landslide, debris flow } \\
\text { or flood) }\end{array}$ & $\begin{array}{l}\text { Whether an early warning has been } \\
\text { received prior to a natural disaster } \\
\text { (landslide, debris flow or flood) } \\
\qquad(0=\text { no, } 1=\text { yes })\end{array}$ & [91] \\
\hline & \multirow{3}{*}{$\begin{array}{l}\text { Climate } \\
\text { variability }\end{array}$} & $\begin{array}{c}\text { Facing gradually increasing } \\
\text { natural disasters } \\
\text { in recent years }\end{array}$ & $\begin{array}{l}\text { Whether there been any changes in the } \\
\text { frequency of disasters in recent years } \\
\qquad(0=\text { no, } 1=\text { yes })\end{array}$ & {$[91]$} \\
\hline & & $\begin{array}{l}\text { Concerns about } \\
\text { climate change }\end{array}$ & $\begin{array}{l}\text { How worried are you about the possible } \\
\text { effects of climate change on your home? } \\
\qquad(1=\text { not worried at all, } \\
5=\text { very worried })\end{array}$ & $\begin{array}{c}\text { Developed for the purposes } \\
\text { of this questionnaire }\end{array}$ \\
\hline & & $\begin{array}{l}\text { Degree of soil and } \\
\text { water loss }\end{array}$ & $\begin{array}{l}\text { Degree of soil erosion of home land } \\
(1=\text { not serious, } 5=\text { very serious })\end{array}$ & $\begin{array}{c}\text { Developed for the purposes } \\
\text { of this questionnaire }\end{array}$ \\
\hline \multirow{9}{*}{ Sensitivity } & Consumption & $\begin{array}{l}\text { Annual per capita } \\
\text { household consumption }\end{array}$ & $\begin{array}{l}\text { Annual per capita consumption } \\
\text { expenditure }\left(\text { Yuan }^{1}\right)\end{array}$ & {$[78]$} \\
\hline & Debt & Household debt & $\begin{array}{l}\text { Whether the household borrowed from } \\
\text { financial channels or from relatives and } \\
\text { friends during the previous five years } \\
\qquad(0=\text { no, } 1=\text { yes })\end{array}$ & {$[78]$} \\
\hline & $\begin{array}{c}\text { Area of } \\
\text { mountainous area }\end{array}$ & $\begin{array}{l}\text { The ratio of mountain area to } \\
\text { total area of family }\end{array}$ & $\begin{array}{c}\text { The percentage of the total area of the } \\
\text { home that is mountainous }\end{array}$ & $\begin{array}{c}\text { Developed for the purposes } \\
\text { of this questionnaire }\end{array}$ \\
\hline & \multirow{4}{*}{ Health } & Genetic disorder & $\begin{array}{l}\text { Whether anyone in the family has a } \\
\text { genetic disease/major genetic disorder } \\
\qquad(0=\text { no, } 1=\text { yes })\end{array}$ & {$[92,93]$} \\
\hline & & Sanitary latrine & $\begin{array}{l}\text { Whether there is a sanitary latrine in } \\
\text { your home }(0=\text { no, } 1=\text { yes })\end{array}$ & {$[92,93]$} \\
\hline & & $\begin{array}{l}\text { The number of people who } \\
\text { need help }\end{array}$ & $\begin{array}{l}\text { Whether there are people in the family } \\
\text { who need help because they are } \\
\text { old/unable to move well } \\
(0=\text { no, } 1=\text { yes })\end{array}$ & $\begin{array}{c}\text { Developed for the purposes } \\
\text { of this questionnaire }\end{array}$ \\
\hline & & $\begin{array}{l}\text { New Rural Cooperative } \\
\text { Medical Insurance }\end{array}$ & $\begin{array}{l}\text { Whether the family has purchased the } \\
\text { new rural cooperative medical insurance } \\
\text { (the so-called medical insurance) } \\
(0=\text { no, } 1=\text { yes })\end{array}$ & $\begin{array}{c}\text { Developed for the purposes } \\
\text { of this questionnaire }\end{array}$ \\
\hline & Food & $\begin{array}{l}\text { Whether the crops have been } \\
\text { affected/reduced by the } \\
\text { disaster/weather }\end{array}$ & $\begin{array}{l}\text { Have the crops have been } \\
\text { affected/reduced by the } \\
\text { disaster/weather? }(0=\text { no, } 1=\text { yes })\end{array}$ & $\begin{array}{c}\text { Developed for the purposes } \\
\text { of this questionnaire }\end{array}$ \\
\hline & Water & $\begin{array}{c}\text { Availability of } \\
\text { Water Resources }\end{array}$ & $\begin{array}{l}\text { Whether the present water resources can } \\
\text { meet the basic needs of production and } \\
\text { living }(0=\text { no, } 1=\text { yes })\end{array}$ & {$[35,91]$} \\
\hline \multirow{3}{*}{$\begin{array}{l}\text { Livelihood } \\
\text { Resilience }\end{array}$} & \multirow{3}{*}{ Human capital } & Education level & $\begin{array}{c}\text { Ratio of Population with High School } \\
\text { Education or above to } \\
\text { Total Population (\%) }\end{array}$ & {$[94-96]$} \\
\hline & & $\begin{array}{l}\text { Proportion of population in } \\
\text { the labor force }\end{array}$ & Labor force to total population ratio (\%) & {$[94-96]$} \\
\hline & & Skills & $\begin{array}{l}\text { Ratio of people with skills to } \\
\text { total population }(\%)\end{array}$ & {$[94-96]$} \\
\hline
\end{tabular}


Table 1. Cont.

\begin{tabular}{|c|c|c|c|c|}
\hline $\begin{array}{c}\text { IPCC } \\
\text { Contributing } \\
\text { Factor }\end{array}$ & $\begin{array}{c}\text { Major } \\
\text { Dimensions }\end{array}$ & Subdimensions & Explanation & Source \\
\hline & \multirow{2}{*}{ Natural capital } & $\begin{array}{l}\text { Per capita cultivated } \\
\text { land area }\end{array}$ & $\begin{array}{l}\text { Ratio of cultivated land area in operation } \\
\text { to total population }\left(\mathrm{Mu}^{2} / \text { person) }\right.\end{array}$ & [94-96] \\
\hline & & Per capita forestland area & $\begin{array}{l}\text { Ratio of operating forestland area to total } \\
\text { population }\left(\mathrm{Mu}^{2} / \text { person) }\right.\end{array}$ & [94-96] \\
\hline & \multirow{2}{*}{ Financial capital } & Per capita annual income & $\begin{array}{l}\text { Ratio of total cash income to total } \\
\text { number of persons (Yuan } 1 / \text { person) }\end{array}$ & [94-96] \\
\hline & & Deposits & $\begin{array}{l}\text { Whether they have a deposit } \\
\qquad(\text { no }=0 \text {, yes }=1)\end{array}$ & [94-96] \\
\hline & \multirow{3}{*}{ Social capital } & $\begin{array}{c}\text { Participate in } \\
\text { association organization }\end{array}$ & $\begin{array}{l}\text { Number of associations they participate } \\
\text { in (number) }\end{array}$ & {$[94-96]$} \\
\hline & & Social network & $\begin{array}{c}\text { Number of families visiting relatives and } \\
\text { friends during } \\
\text { the Spring Festival (number) }\end{array}$ & [94-96] \\
\hline & & Members of employment & $\begin{array}{l}\text { Whether they have relatives in the } \\
\text { village or township cadres or in roles as } \\
\text { other public officials (such as teachers, } \\
\text { civil servants) (number) }\end{array}$ & [94-96] \\
\hline & Physical capital & Present value of fixed assets & $\begin{array}{l}\text { Present value of agriculture, housing and } \\
\text { other fixed assets }\end{array}$ & {$[94-96]$} \\
\hline
\end{tabular}

${ }^{1}$ During the study period, USD 1 was equal to CNY $6.96 .{ }^{2} 1 \mathrm{mu}=667 \mathrm{~m}^{2}$, or 0.667 ha.

Sensitivity reflects the extent to which the region is affected by extreme weather changes [88], and farm households will show significant fluctuations in consumption and even borrowing behavior when subjected to landslide shocks, agricultural shocks, and other economic expenditure shocks [78]. Additionally, considering that the study area is prone to landslides, debris flows and flash floods, the more mountainous area occupied by farm households will show more sensitive characteristics when other factors are not considered. When disasters occur, the drinking water, health and food of farm households are easily affected. Therefore, the sensitivity dimension is selected to measure consumption, debt, mountain area, healthy food, and water resources.

Livelihood resilience depends on available access to resources and will determine the extent to which individuals, households, and communities can absorb shocks, and this study takes livelihood resilience in terms of livelihood capital, i.e., it can increase opportunities to engage in risk management and cope with shocks [97]. The livelihood resilience dimension was selected to measure the human, natural, financial, social and material capital of farm households. Human capital includes physical health quality and scientific and cultural quality, and is mainly measured by the degree of higher education, the proportion of the population that is the labor force, and the proportion of the population with skills; natural capital reflects the extent of farmers' use of natural resources, and is mainly quantified by the area of arable land and forest land being operated per capita; financial capital refers to the capital available to farmers, including accumulated capital and liquid capital, and is mainly quantified by the annual income per capita. Financial capital refers to the capital available to farmers, including accumulated capital and liquid capital, and is mainly quantified by the annual cash income per capita and the availability of savings. Social capital reflects the ability of farmers to use social networks to implement livelihood strategies, and is mainly measured by the amount of association participation, social network, and family members' state public office status. Material capital refers to the relatively fixed resources owned by farmers to cope with climate change, and is mainly quantified by the present value of fixed assets.

Referring to studies such as Liu et al. and Zhou et al. [67,98], we also take into account the characteristics that the income of Chinese farmers mainly consists of multiple components such as agricultural income, wage income, property income, and transfer 
income. This study measures the livelihood strategies of farming income as a proportion of annual household cash income, and classifies them into three categories: pure farming, parttime farming, and nonfarming. Among them, those whose agricultural income accounted for less than $50 \%$ of total household income were nonfarm livelihood strategies, those greater than or equal to $50 \%$ but less than or equal to $80 \%$ were part-time livelihood strategies, and those greater than $80 \%$ were purely farm livelihood strategies

\subsection{Calculation}

\subsubsection{The Entropy Method}

Most of the 13 major components of the Livelihood Vulnerability Index (IPCC-LVI) under the IPCC framework consist of several indicators. Referring to the research of Peng et al. [78], the entropy method was adopted in this paper to determine the weight of each indicator and the comprehensive score of each dimension. The entropy method is an objective, weighting, mathematical method used to judge the dispersion degree of each index: the smaller the entropy value, the greater the dispersion degree, and the greater the influence (i.e., weight) of the index on the Comprehensive Evaluation. Compared with qualitative methods such as the Delphi method and analytic hierarchy process, the results of the entropy method are more objective and accurate. After determining the weights and evaluation scores of each indicator, the following formula was used to calculate IPCC-LVI by referring to the studies of Azam et al., the IPCC and Nguyen et al. [21,40,99]. The vulnerability index ranges from -1 (the least vulnerable) to 1 (the most vulnerable).

$$
I P C C-L V I=(\operatorname{Exp}-L R) * \operatorname{Sen}
$$

Among them, IPCC-LVI is the score of the livelihood vulnerability index; Exp is the score of the exposure dimension; $L R$ is the score of the livelihood resilience dimension; Sen is the score of the sensitivity dimension.

\subsubsection{Econometric Model}

To explore the degree and direction of influence of different factors on the choice of livelihood strategies, regression analysis of the influencing factors is required. Ordered multicategorical logistic-regression models are usually used for the analysis of influencing factors where the dependent variable is tricategorical and above and there is a concurrent ordinal relationship between the categories. Referring to the study by Zhou et al. [67], considering the dependent variable is the type of farmers' livelihood strategies, it is more appropriate for classification as an ordered categorical variable. The independent variables are the vulnerability to landslide, debris flow, flood disaster, which fall into the classification of continuous variables. Thus, this study attempts to build an ordinal multinomial logisticregression model to explore different disaster vulnerabilities and the relevant relationship between the livelihood of farmers and adopted strategies. The simple expression for the model is as follows:

$$
Y=\alpha_{0}+\alpha_{1} \times \text { livelihood vulnerability index } x_{i}+\varepsilon_{i}
$$

where $Y$ is the livelihood strategy of residents; livelihood vulnerability index is the core independent variable of the model, reflecting the vulnerability of farmers to different disasters, $\alpha_{0}, \alpha_{1}, \beta_{0}, \beta_{1}$ represent the parameter estimations of the model, respectively, while $\varepsilon_{i}$ and $\sigma_{i}$ are the residuals of the model. The whole process is realized by Stata13.0.

\section{Results and Analysis}

\subsection{Descriptive Statistical Analysis of Livelihood Vulnerability}

Table 2 provides the basic data and weights for the IPCC-LVI. In terms of the exposure dimension, farmers experienced a landslide, debris flow and flood on average 8.6 times, $20 \%$ of the farmers had someone they know be injured or die because of the disaster, $22 \%$ of the farmers did not receive the warning information when the disaster happened, 
and $76 \%$ of the farmers felt the increase in the number of disasters in recent years and expressed some worry. In terms of sensitivity, the average per capita annual consumption of households in 2018 was USD 1436.78, and 56\% of households had debt. In terms of health, $21 \%$ of households reported that someone in their household had a genetic or serious disease, $71 \%$ had clean toilets and $68 \%$ had health insurance. In terms of food, $52 \%$ of the farmers' crops were reduced by the disaster, and $5 \%$ said water resources could not meet their basic production and living needs. In terms of human capital, only $16 \%$ of households have a high school degree or above, only $58 \%$ of households have labor force, and only $24 \%$ of households have skills. As far as natural capital is concerned, the average area of cultivated land operated by farmers is $0.82 \mathrm{mu}\left(546.94 \mathrm{~m}^{2}\right)$, and the average area of forested land is $7.56 \mathrm{mu}\left(5042.52 \mathrm{~m}^{2}\right)$. In terms of financial capital, the per capita income of farmers was USD 2298.85 in 2018, and $46 \%$ of farmers had savings. In terms of social capital, the average farmer participates in 0.16 social organizations, and visits 5.27 households on average during the Spring Festival. The average farmer has at least one relative who is a village cadre. In terms of physical capital, the farmer households have an average of USD 65,890.80 in present value of physical assets.

Table 2. Basic statistics and weight of the IPCC-LVI measurement. (Source: the author, 2021).

\begin{tabular}{|c|c|c|c|c|c|}
\hline $\begin{array}{c}\text { IPCC } \\
\text { Contributing } \\
\text { Factor }\end{array}$ & Major Dimensions & Subdimensions & Mean & SD & Weight \\
\hline \multirow{6}{*}{ Exposure } & \multirow{3}{*}{ Natural disaster } & Landslide, debris flow or flood shock & 8.58 & 12.70 & 0.04239 \\
\hline & & Injury & 0.20 & 0.40 & 0.10753 \\
\hline & & $\begin{array}{l}\text { Circumstances of households that do not receive a warning } \\
\text { before a natural disaster (landslide, debris flow or flood) }\end{array}$ & 0.22 & 0.41 & 0.01616 \\
\hline & \multirow{3}{*}{ Climate variability } & Facing gradually increasing natural disasters in recent years & 0.76 & 0.43 & 0.01852 \\
\hline & & Concerns about climate change & 3.51 & 1.24 & 0.01119 \\
\hline & & Degree of soil and water loss & 2.84 & 1.36 & 0.02279 \\
\hline \multirow{9}{*}{ Sensitivity } & Consumption & Annual per capita household consumption & $10,053.94$ & $11,633.08$ & 0.02365 \\
\hline & Debt & Household debt & 0.56 & 0.50 & 0.03795 \\
\hline & Area of mountainous area & The ratio of mountain area to total area of home & 0.27 & 0.43 & 0.08095 \\
\hline & \multirow{4}{*}{ Health } & Genetic disorder & 0.33 & 0.47 & 0.07370 \\
\hline & & Sanitary latrine & 0.71 & 0.45 & 0.08223 \\
\hline & & The number of people who need help & 0.21 & 0.41 & 0.10258 \\
\hline & & New Rural Cooperative Medical Insurance & 0.68 & 0.47 & 0.07432 \\
\hline & Food & $\begin{array}{c}\text { Whether the crops have been affected/reduced by the } \\
\text { disaster/weather }\end{array}$ & 0.52 & 0.50 & 0.04279 \\
\hline & Water & Availability of Water Resources & 0.95 & 0.22 & 0.19050 \\
\hline \multirow{11}{*}{$\begin{array}{l}\text { Livelihood } \\
\text { Resilience }\end{array}$} & \multirow{3}{*}{ Human capital } & Education level & 0.16 & 0.21 & 0.00067 \\
\hline & & Proportion of population in the labor force & 0.58 & 0.30 & 0.02132 \\
\hline & & Skills & 0.24 & 0.24 & 0.00364 \\
\hline & \multirow{2}{*}{ Natural capital } & Per capita cultivated land area & 0.82 & 2.28 & 0.00027 \\
\hline & & Per capita forestland area & 7.56 & 18.48 & 0.00088 \\
\hline & \multirow{2}{*}{ Financial capital } & Per capita annual income & $16,440.90$ & 18241.39 & 0.00037 \\
\hline & & Deposits & 0.46 & 0.50 & 0.04051 \\
\hline & \multirow{3}{*}{ Social capital } & Participate in association organization & 0.16 & 0.38 & 0.00179 \\
\hline & & Social network & 5.27 & 8.15 & 0.00036 \\
\hline & & Members of the employment & 1.50 & 2.99 & 0.00127 \\
\hline & Physical capital & Present value of fixed assets & 45.86 & 67.29 & 0.00166 \\
\hline
\end{tabular}

Definition of weight: the smaller the entropy value of the indicator, the greater the dispersion, and the greater the influence (i.e., weight) of the indicator on the comprehensive evaluation.

The entropy method is used to obtain the weight of each dimension index. As shown in the last column of Table 2, the weight of water resources reflecting sensitivity is the highest (0.1905), followed by the weight of casualties caused by disasters (0.1075), and the weight of humans in need of help due to poor mobility in the family is relatively high (0.10753). Access to a clean toilet at home, proportion of mountainous areas, purchase 
of medical insurance and genetic/major diseases were also highly weighted (all greater than 0.05). Additionally, the weights of disaster, deposits, loans, weight per capita consumption, the degree of soil and water loss, and labor are relatively high (not less than 0.02). The weights of increasing awareness of natural disasters, not receiving early warnings and climate change concerns were higher (not less than 0.01) than the weights of high index, skills, social organization, physical assets, civil servants, woodland area of business, education level, per capita annual income, social network and the management of arable land per capita, which are relatively low (less than 0.005).

Table 3 shows the comprehensive value of the IPCC-LVI of farmers in different naturaldisaster-threatened areas. Among the three disaster types, landslide, debris flow and flood, the IPCC-LVI (0.1155) of farmers in landslide-threatened areas is much higher than that of debris-flow- (0.0605) and flood-threatened areas (0.0238), and the IPCC-LVI of the main components is between 0.0001 and 0.0553 . The specific index of livelihood vulnerability of farmers in the three types of natural-disaster-threatened areas was compared (as shown in Figure 2). Among the landslide disaster types, the vulnerability of the sensitivity dimension (0.1008) was higher than that of the exposure dimension $(0.038)$ and the livelihood resilience dimension (0.0232). Specifically, health (0.0553), natural disasters $(0.0207)$ and weather-change conditions (0.0173) were the most vulnerable. In contrast, physical capital (0.0008), consumption (0.0008) and natural capital (0.0006) are the least vulnerable. Among the types of debris-flow disasters, the vulnerability of the sensitivity dimension (0.0516) is much higher than the vulnerability score of the exposure dimension (0.0223) and the vulnerability score of the livelihood-resilience dimension (0.0133). Specifically, health (0.0289), natural disasters $(0.0121)$ and weather changes $(0.0101)$ were the most vulnerable, while physical capital (0.0005), consumption (0.0005) and natural capital (0.0003) were the least vulnerable. The vulnerability of the sensitivity dimension (0.0189) was higher than that of the exposure dimension (0.0086) and the livelihood-resilience dimension (0.0037) in the flood disaster types. Specifically, the vulnerability degree of water (0.0093), consumption (0.0045) and natural capital (0.004) was the highest, while the vulnerability degree of mountain area (0.0002), natural disaster $(0.0001)$ and food (0.0001) was the lowest (as shown in Figure 3).

Table 3. Livelihood vulnerability index of different disasters. (Source: the author, 2021).

\begin{tabular}{|c|c|c|c|c|c|c|c|}
\hline \multirow{2}{*}{$\begin{array}{l}\text { IPCC Contributing } \\
\text { Factor }\end{array}$} & \multicolumn{3}{|c|}{ IPCC Contributing Factor Value } & \multirow{2}{*}{ Major Components } & \multicolumn{3}{|c|}{ Major Component Value } \\
\hline & Landslide & Debris Flow & Flood & & Landslide & Debris Flow & Flood \\
\hline \multirow{5}{*}{ Livelihood Resilience } & \multirow{5}{*}{0.0232} & \multirow{5}{*}{0.0133} & \multirow{5}{*}{0.0037} & Human capital & 0.0071 & 0.0038 & 0.0013 \\
\hline & & & & Natural capital & 0.0006 & 0.0003 & 0.0001 \\
\hline & & & & Financial capital & 0.0128 & 0.0078 & 0.0017 \\
\hline & & & & Social capital & 0.0018 & 0.0010 & 0.0004 \\
\hline & & & & Physical capital & 0.0008 & 0.0005 & 0.0002 \\
\hline \multirow{6}{*}{ Sensitivity } & \multirow{6}{*}{0.1008} & \multirow{6}{*}{0.0516} & \multirow{6}{*}{0.0189} & Consumption & 0.0008 & 0.0005 & 0.0001 \\
\hline & & & & Debt & 0.0123 & 0.0063 & 0.0028 \\
\hline & & & & Area of mountainous area & 0.0125 & 0.0070 & 0.0026 \\
\hline & & & & Health & 0.0553 & 0.0289 & 0.0093 \\
\hline & & & & Food & 0.0128 & 0.0067 & 0.0029 \\
\hline & & & & Water & 0.0070 & 0.0023 & 0.0012 \\
\hline \multirow{2}{*}{ Exposure } & \multirow{2}{*}{0.0380} & \multirow{2}{*}{0.0223} & \multirow{2}{*}{0.0086} & Natural disaster & 0.0207 & 0.0121 & 0.0045 \\
\hline & & & & Climate variability & 0.0173 & 0.0101 & 0.0040 \\
\hline IPCC-LVI & 0.1155 & 0.0605 & 0.0238 & & & & \\
\hline
\end{tabular}




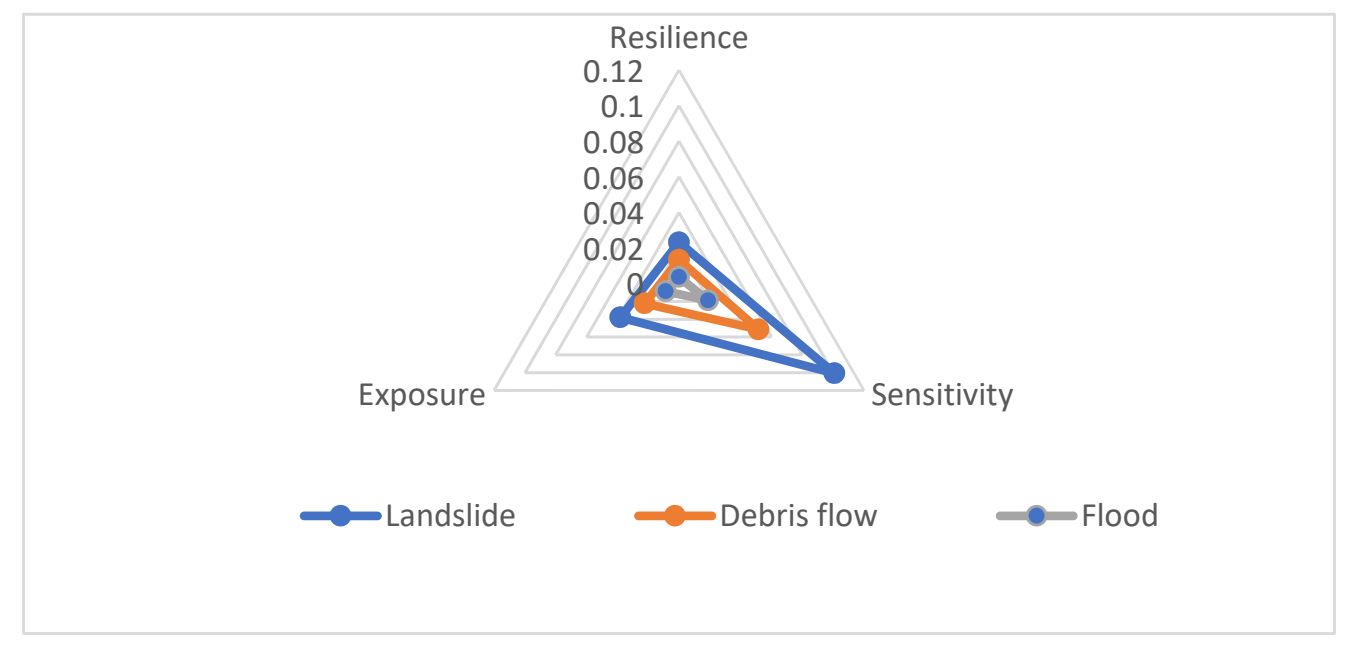

Figure 2. Tringle diagram of vulnerability of different types of disasters based on IPCC-LVI scores. (Source: the author, 2021).

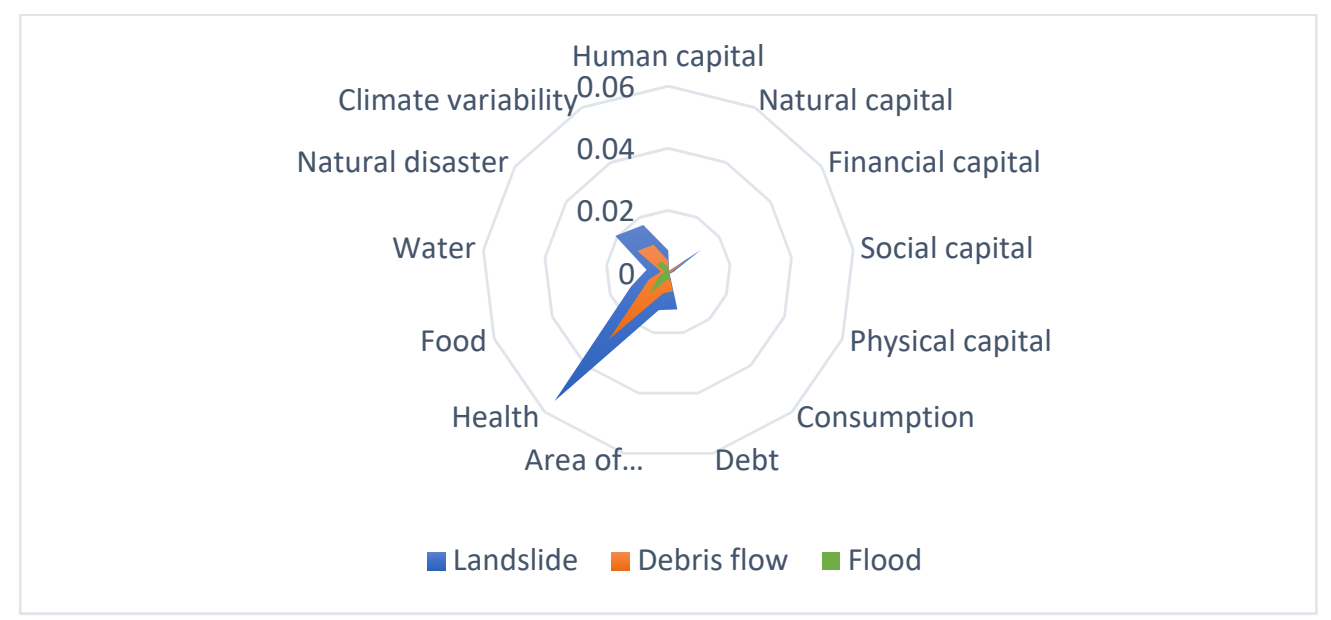

Figure 3. Spider diagram of the major components of IPCC-LVI for different types of disasters. (Source: the author, 2021).

According to data collection and statistics, nonagricultural households in the sample area accounted for the vast majority, 294 households in total, accounting for $89.91 \%$; there were 13 concurrent farming households, accounting for $3.98 \%$; there were 20 pure agricultural households, accounting for $6.12 \%$. Table 4 shows the comprehensive value of different livelihood-strategy choices of farmers. Among the three natural disasters, the vulnerability of farmers' nonfarming livelihood strategy (0.0042) is much higher than that of part-time livelihood strategy (0.0002) and pure farming livelihood strategy (0.0002) (as shown in Figure 4), and the vulnerability score of its main components ranges from 0 to 0.0847 . Specifically comparing the indicators of the three livelihood strategies, the vulnerability of sensitivity dimension (0.1533) was significantly higher than the vulnerability of exposure dimension (0.0616) and the vulnerability of livelihood resilience dimension (0.0352) in nonagricultural livelihood strategies. Specifically, the vulnerability levels of health (0.0847), natural disasters $(0.0336)$ and climate change $(0.028)$ were the highest, while physical capital (0.0013), consumption (0.0013) and natural capital (0.001) were the lowest. In the part-time livelihood strategy, the vulnerability of sensitivity dimension (0.0069) was higher than the vulnerability of exposure dimension (0.0029) and the vulnerability of livelihood resilience dimension (0.0019). Specifically, water resources (0.003), consumption (0.0015) and natural capital (0.0014) were the most vulnerable, while consumption (0.0001), natural disasters (0) and mountain proportions (0) were the least vulnerable. In the pure agricul- 
tural livelihood strategy, the vulnerability of sensitivity dimension (0.0111) was higher than that of exposure dimension (0.0042) and livelihood resilience dimension (0.0031). Specifically, health $(0.0058)$, natural disasters $(0.0022)$ and mountain proportions $(0.0021)$ are the most vulnerable, while consumption (0.0001), physical capital (0.0001) and climate change (0.0001) are the least vulnerable (Figure 5).

Table 4. Livelihood vulnerability index of different livelihood strategies. (Source: the author, 2021).

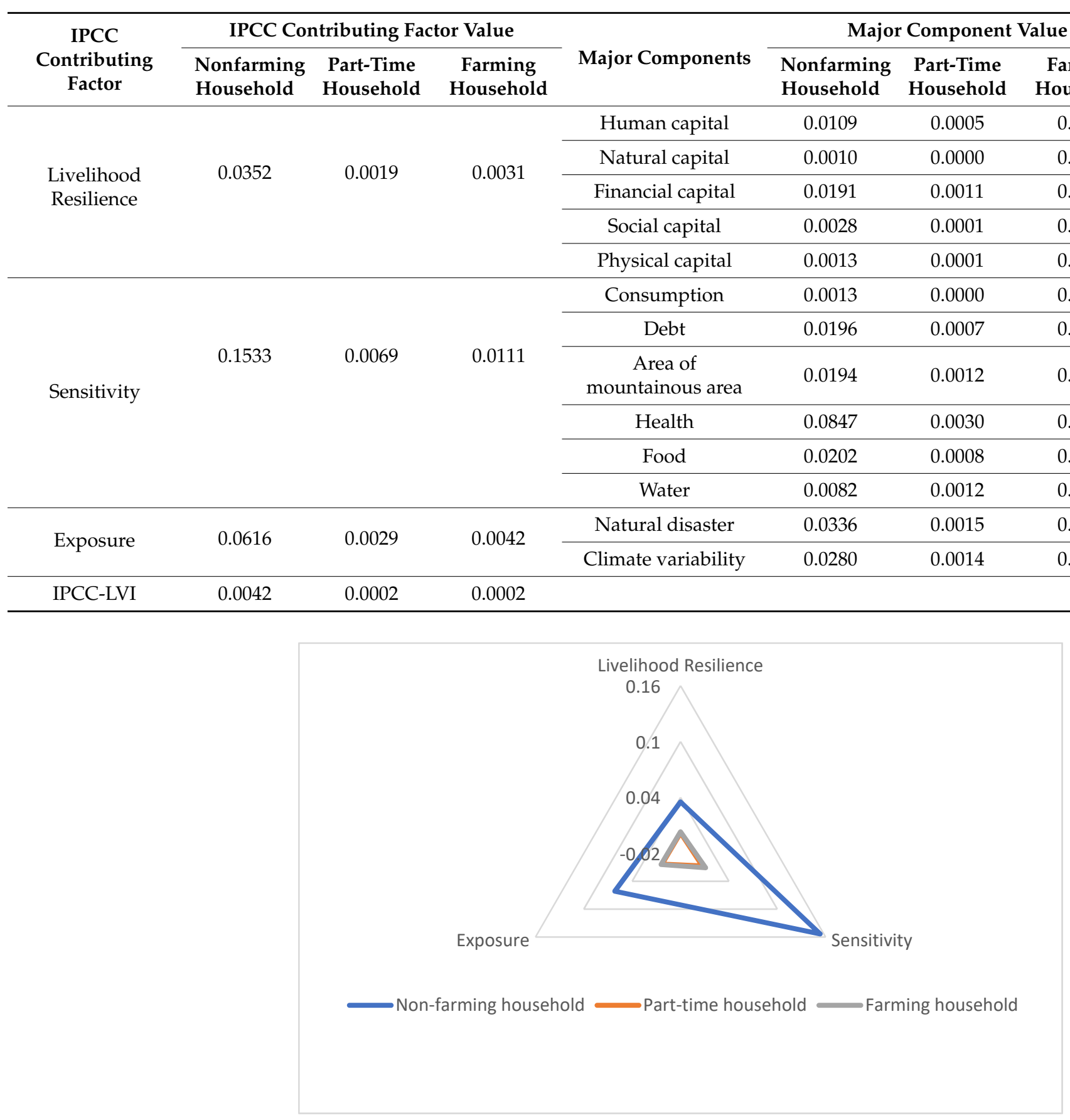

Figure 4. Triangle diagram of vulnerability of different types of livelihoods strategies based on IPCC-LVI scores. (Source: the author, 2021). 


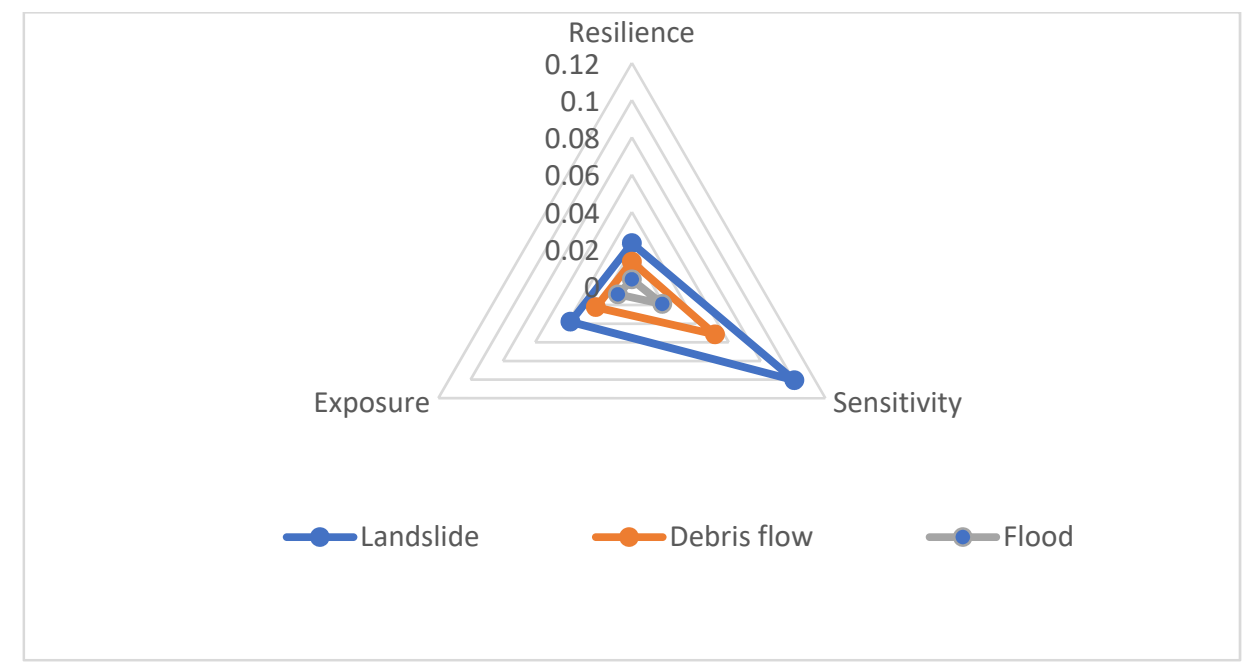

Figure 5. Spider diagram of the major components of IPCC-LVI for different livelihoods strategies. (Source: the author, 2021).

\subsection{Results of the Econometric Model}

Table 5 shows the regression results of household livelihood vulnerability and livelihoodstrategy choice in different disaster-type-threatened areas. According to the $P$ value $(0.0918<0.1)$ corresponding to the overall significance test of the model, it can be seen that the model has passed the overall significance test. In general, vulnerability of the livelihood resilience dimension is positively related to the choice of purely farm-based livelihood strategies by farm households. Specifically for a disaster type, regarding landslide disaster, the vulnerability of the livelihood resilience dimension of farmers is significantly positively correlated with the livelihood strategy. Under the premise that other conditions remain unchanged, the logarithmic probability of farmers choosing the pure agricultural livelihood strategy increases by 38.6358 for each unit increase in the vulnerability of the livelihood resilience dimension. Considering the debris-flow disaster, the livelihood resilience of farmers and their livelihood strategies are significantly positively correlated. Under the premise that other conditions remain unchanged, the logarithmic probability of choosing a pure agricultural livelihood strategy increases by 55.98425 for each unit of vulnerability of the livelihood resilience dimension.

Table 5. Regression results of household livelihood vulnerability and livelihood-strategy choice in different disaster-type-threatened areas. (Source: the author, 2021).

\begin{tabular}{ccccc}
\hline \multirow{2}{*}{ Variable } & \multicolumn{3}{c}{ Types of Natural Disasters } & \multirow{2}{*}{$\begin{array}{c}\text { The Overall } \\
\text { Sample }\end{array}$} \\
\cline { 2 - 4 } & Landslide & Debris Flow & Flood & -0.1218 \\
Exposure & -4.0388 & 9.9804 & 5.4835 & $(-3.7563)$ \\
& $(-5.4787)$ & $(-7.0540)$ & $(-12.6898)$ & -0.5770 \\
Sensitivity & -2.0608 & 1.2832 & 5.0520 & $(-2.0442)$ \\
& $(-2.4139)$ & $(-4.9882)$ & $(-4.6718)$ & $24.33493 * *$ \\
Livelihood Resilience & $38.6358^{* *}$ & $55.98425 * * *$ & -21.6745 & $(-10.2524)$ \\
IPCC-LVI & $(-15.4285)$ & $(-19.1197)$ & $(-32.4878)$ & -10.7671 \\
& -43.53353 & 31.47006 & 5.687566 & $(22.5154)$ \\
\hline$N$ & $(33.00933)$ & $(31.21301)$ & $(59.93277)$ & 327 \\
Prob $>$ chi2 & 189 & 99 & 39 & 0.0918 \\
$\mathrm{R}^{2}$ & 0.0917 & 0.0000 & 0.7397 & 0.0290 \\
\hline Notes: *** $p<0.01$ ** $p<0.05$. Figures in parentheses are robust standard error & 0.0289 &
\end{tabular}




\section{Discussions}

This study empirically analyzed the correlation between vulnerability indices and livelihood strategies for different hazards using survey data from farm households in three different natural-hazard-threatened areas: landslides, debris flows and flash floods.

The results of this study are consistent with the research hypothesis H1, and consistent with the findings of Ashikin et al., Gerlitz et al. and Shah and Dulal, that there are significant differences in the dimensions of livelihood vulnerability of farm households in different disaster-threatened zones $[39,100,101]$. However, in this study, when the different hazards to which farm households were subjected were compared cross-sectionally, it was found that the degree of livelihood vulnerability of farm households in landslide-threatened areas was much higher than that of farm households in debris-flow- and flash-flood-threatened areas. At the same time, all three natural hazards show one shared characteristic: the highest vulnerability score for the sensitivity dimension, the second for the exposure dimension, and the third for the livelihood resilience dimension. This suggests that farm households in landslide-hazard-threatened areas exhibit more vulnerable characteristics than those in the other two hazard threat areas, and that the indirect effects of disasters on households make farm households more vulnerable than direct shocks do. Possible reasons for this are: Firstly, the location of farm households in the mountainous regions of western China is scattered, and farm households in different locations are exposed to different natural hazards and their threat levels differ significantly when other factors are not considered. Secondly, landslides triggered by extreme weather are more common, while mudslide and flood disasters are more predictable under strong rainstorm conditions. Thirdly, the indicators of the sensitivity dimension (e.g., consumption, indebtedness, etc.) are directly or indirectly affected by climate change, in particular the subsequent impact of disasters on socioeconomics tends to have a greater impact on farm households, while the indicators of the exposure dimension are mainly affected by climate change directly, and appropriate measures can effectively reduce the degree of vulnerability.

The results of this study are consistent with the research hypothesis $\mathrm{H} 2$, and there are significant differences in the dimensions of vulnerability among farmers who adopt different livelihood strategies. The vulnerability of farmers who chose nonfarm livelihood strategies was much higher than the vulnerability of part-time and pure-farm farmers' livelihood strategies, and all three showed a trend of higher vulnerability in the sensitivity dimension than in the exposure and livelihood resilience dimensions. This suggests that farm households living under the impact of natural disasters for long periods of time are more vulnerable and more significantly affected by indirect impacts by choosing nonfarm livelihood strategies. Therefore, how to reduce indirect impacts becomes the key to resist natural disaster shocks. This result is similar to the study of Bhattacharjee and Behera [38], who found that households that depend on agricultural activities for income are less vulnerable compared to those engaged in nonagricultural activities, and that pure farming households have been exposed to disasters for a long time and have even developed a way of life where they respond to disaster emergencies in a flexible manner; while in nonagricultural households, the labor force mainly works in towns/urban areas, but the household stays in the rural areas, putting great pressure on coping with disasters due to lack of adequate resources. However, this is inconsistent with the findings of Hoq et al. [80], as he argues that households engaged in multiple income-generating activities are relatively less vulnerable while working outside the home is an effective way to reduce vulnerability.

The results of this study are inconsistent with research hypothesis H3, but are consistent with the findings of Hahn et al., Sujakhu et al. and Poudel, among others, which also found that livelihood vulnerability of farm households in natural-disaster-threatened areas is significantly associated with their livelihood strategy choices [35,36,95]. This suggests that by enhancing the livelihood resilience of farmers in affected areas, it can influence the choice of pure agriculture and provide a way to adjust livelihood strategies. Poudel argues that farm households engaged in nonagricultural activities are more vulnerable in the exposure dimension than those engaged in pure agriculture [36], while this study 
found that the vulnerability of the livelihood resilience dimension is positively correlated with farmers' engagement in pure agricultural activities. Possible reasons for this are: Firstly, the capital stock of farm households in western China tends to decrease gradually with the nonfarming of household livelihoods [102], and the stronger the livelihood resilience, i.e., the richer the livelihood capital stock, the higher the likelihood that they will specialize in agriculture. Secondly, agricultural income is an important influencing factor of livelihood resilience, where the more capital stock farmers have, the more income they earn from agriculture, and the more likely they are to invest in productive resources to continue to develop the industry [103].

Compared with other studies, the marginal contributions of this study are: Firstly, this research uses the IPCC vulnerability-assessment framework to analyze the characteristics and differences of farmers' livelihood vulnerability in different natural-disastertype-threatened areas. Secondly, this study classifies the IPCC-LVI of farmers into the three dimensions of exposure, sensitivity and livelihood resilience, and classifies farmers' livelihood strategies into pure farming, part-time and nonfarming types. The study systematically analyzed the characteristics and differences of farmers' livelihood vulnerability and livelihood strategies and constructed a model to explore the correlation between farmers' livelihood vulnerability and livelihood strategies in different natural-disaster-threatened zones. The research design can provide a reference for other similar studies.

Despite the useful exploration in this study, there are still some limitations to be overcome: Firstly, the endogeneity of variable selection was not considered in the analysis of the livelihood vulnerability index. Secondly, the study area was limited to Sichuan, and the considered types of natural disasters under climate change conditions were only landslides, debris flows, and floods, and the applicability of the study results to other regions and other natural-disaster types needs further validation. Thirdly, this study only used the static time node data of 2019 for the exploratory study of vulnerability and livelihood strategies.

Therefore, the following suggestions for further research are proposed: Firstly, when considering the measurement of vulnerability indices in future studies, it is more important to design a comprehensive evaluation index system to measure different dimensions of vulnerability indices, and it is necessary to consider the issues of mediating effects and endogenous variable selection. Meanwhile, an attempt can be made to use the vulnerability index system to assess farmers in other disaster areas. Secondly, the livelihood strategies adopted by farmers are dynamic, and further research on livelihood strategy-driving mechanisms can be conducted in the future using dynamic panel data.

\section{Conclusions}

Based on the survey data of 327 rural households in areas threatened by the three natural disasters of landslides, debris flows and floods, the characteristics of farmers' livelihood vulnerability and adaptation strategies in different disaster-type-threatened areas were analyzed, and an ordered multiclassification logistic-regression model was constructed to explore the correlation.

Indicator values for each component and subcomponent of farmers' livelihood vulnerability and livelihood strategy options differed significantly across regions, which provides insight into the development and implementation of policies related to the reduction of farmers' livelihood vulnerability and adaptation of livelihood strategies in specific regions. For example, it was found that indicators such as water resources, casualties due to disasters, and whether someone in the household is unable to take care of himself/herself had the highest weight in the livelihood vulnerability-assessment system, and water resources also had the highest level of vulnerability among flood hazard types. Based on this, it is recommended that the government increase the provision of water resources in landslide- and mudslide-threatened areas. Again, it was found that the degree of vulnerability of livelihood resilience was positively correlated with farmers choosing purely farm-based livelihood strategies, while income sources and livelihood diversification op- 
tions are crucial to reduce the vulnerability of local communities $[66,104]$. Based on this, it is recommended that the government should encourage farm household labor to learn skills and acquire technology to increase income sources, enrich livelihood capital, and improve livelihood resilience, while considering regional equity. In addition, the human capital possessed by farm households with different livelihood strategies in different disaster types greatly affects the vulnerability index of the livelihood resilience dimension (as shown in Figures 2 and 4), and socioecological innovation is an effective way to achieve sustainable livelihoods [51,105], while the younger generation is the primary group to bear the brunt of sustainability issues [106]. Based on this, it is suggested that the government should give full play to the advantages of geography, blood and industry, and should focus on building rural communities, increasing social responsibility, and creating a common "community garden" through the use of human capital, especially the younger generation, in order to achieve climate change mitigation or adaptation.

Author Contributions: Conceptualization, X.Y. and D.X.; methodology, S.G., W.W. and X.D.; software, X.D.; formal analysis, X.Y. and S.G.; investigation, W.W. and D.X.; writing-original draft preparation, X.Y. and D.X.; writing-review and editing, X.Y. and D.X.; supervision, D.X.; funding acquisition, D.X. All authors have read and agreed to the published version of the manuscript.

Funding: This research was funded by National Natural Science Foundation of China (41801221), Special Program for Cultivating Excellent Young Talents under the Dual Support Plan of Sichuan Agricultural University, Undergraduate research interest cultivation program in 2021 of Sichuan agricultural university $(2021489 ; 2021488)$.

Institutional Review Board Statement: Not applicable.

Informed Consent Statement: Not applicable.

Data Availability Statement: If necessary, we can provide raw data.

Acknowledgments: We gratefully acknowledge financial support from National Natural Science Foundation of China (41801221), Special Program for Cultivating Excellent Young Talents under the Dual Support Plan of Sichuan Agricultural University and the Fundamental Research Funds for the Central Universities (JBK2102018). The authors also extend great gratitude to the anonymous reviewers and editors for their helpful review and critical comments.

Conflicts of Interest: The authors declare that they have no conflict of interest. This article does not contain any studies with human participants or animals performed by any of the authors. Informed consent was obtained from all individual participants included in the study.

\section{References}

1. Intergovernmental Panel on Climate Change (IPCC). Managing the Risks of Extreme Events and Disasters to Advance Climate Change Adapatation; Cambridge University Press: Cambridge, MA, USA, 2012.

2. Intergovernmental Panel on Climate Change (IPCC). Observations: Atmosphere and Surface. In Climate Change 2013: The Physical Science Basis. Contribution of Working Group I to the Fifth Assessment Report of the Intergovernmental Panel on Climate Change; Cambridge University Press: Cambridge, MA, USA, 2013.

3. Archer, D.R.; Fowler, H.J. Characterising flash flood response to intense rainfall and impacts using historical information and gauged data in Britain. J. Flood Risk Manag. 2015, 11, S121-S133. [CrossRef]

4. Arnbjerg-Nielsen, K.; Willems, P.; Olsson, J.; Beecham, S.; Pathirana, A.; Bülow Gregersen, I.; Madsen, H.; Nguyen, V.T.V. Impacts of climate change on rainfall extremes and urban drainage systems: A review. Water Sci. Technol. 2013, 68, 16-28. [CrossRef] [PubMed]

5. Fadhel, S.; Rico-Ramirez, M.A.; Han, D. Sensitivity of peak flow to the change of rainfall temporal pattern due to warmer climate. J. Hydrol. 2018, 560, 546-559. [CrossRef]

6. Li, H.C.; Xie, J.B.; Guo, L.; Kuang, S.F. A review of the study on flash flood early warning in China. Pearl River 2017, 38, 29-35. (In Chinese)

7. Huang, C.H.; Li, G.P.; Zhang, F.L.; Gao, H.Z.; Wang, M.Y.; Guo, S.Y. Evolution characteristics of mountain rainstorm events in Sichuan under the influence of climate change in recent 10 years. Rainstorm Disaster 2020, 39, 335-343. (In Chinese)

8. CNSB (China National Statistical Bureau). China Yearbook of Household Survey in 2017; China Statistical Press: Beijing, China, 2018. (In Chinese)

9. Zhou, W.; Ma, Z.; Guo, S.; Deng, X.; Xu, D. Livelihood capital, evacuation and relocation willingness of residents in earthquake stricken areas of rural China. Saf. Sci. 2021, 141, 105350. [CrossRef]

10. Xue, K.; Guo, S.; Liu, Y.; Liu, S.; Xu, D. Social Networks, Trust, and Disaster-Risk Perceptions of Rural Residents in a Multi-Disaster Environment: Evidence from Sichuan, China. Int. J. Environ. Res. Public Health 2021, 18, 2106. [CrossRef] 
11. Ma, Z.; Guo, S.; Deng, X.; Xu, D. Community resilience and resident's disaster preparedness: Evidence from China's earthquakestricken areas. Nat. Hazards 2021, 108, 567-591. [CrossRef]

12. Qing, C.; Guo, S.; Deng, X.; Xu, D. Farmers' Disaster Preparedness and Quality of Life in Earthquake-prone Areas: The Mediating Role of Risk Perception. Int. J. Disaster Risk Reduct. 2021, 59, 102252. [CrossRef]

13. Yang, X.; Guo, S.; Deng, X.; Xu, D. Livelihood Adaptation of Rural Households under Livelihood Stress: Evidence from Sichuan Province, China. Agriculture 2021, 11, 506. [CrossRef]

14. Bao, X.L.; Zhang, F.W.; Deng, X.; Xu, D.D. Can Trust Motivate Farmers to Purchase Natural Disaster Insurance? Evidence from Earthquake-Stricken Areas of Sichuan, China. Agriculture 2021, 11, 783. [CrossRef]

15. Wu, J.J.; Deng, X.; Xu, D.D. Rural households' disaster risk perception and willingness to evacuate and relocate in earthquakestricken areas: Evidence from Sichuan, China. J. Mt. 2021, 39, 552-562. (In Chinese)

16. Doocy, S.; Daniels, A.; Murray, S.; Kirsch, T.D. The human impact of floods: A historical review of events 1980-2009 and systematic literature review. PLoS Curr. 2013, 5, 1. [CrossRef] [PubMed]

17. Piers, B.; Terry, C.; Ian, D.; Ben, W. At Risk: Natural Hazards, People's Vulnerability and Disasters; Taylor and Francis: London, UK, 2014.

18. Cian, F.; Giupponi, C.; Marconcini, M. Integration of earth observation and census data for mapping a multi-temporal flood vulnerability index: A case study on Northeast Italy. Nat. Hazards 2021, 1, 22. [CrossRef]

19. Kendra, J.M. Review of American Hazardscapes: The Regionalization of Hazards and Disasters edited by Susan, L. Cutter. Nat. Hazards Rev. 2003, 4, 222-223. [CrossRef]

20. Cutter, S.L.; Finch, C. Temporal and spatial changes in social vulnerability to natural hazards. Proc. Natl. Acad. Sci. USA 2008, 105, 2301-2306. [CrossRef] [PubMed]

21. Chambers, R. Vulnerability, coping and policy (Editorial Introduction). IDS Bull. 1989, 20, 1-7. [CrossRef]

22. Intergovernmental Panel on Climate Change (IPCC). Climate Change 2001: Impacts, Adaptation, and Vulnerability. Contribution of Working Group II to the Third Assessment Report of the Intergovernmental Panel on Climate Change, Working Group II Impacts Adaptation and Vulnerability; Cambridge University Press: Cambridge, UK, 2001.

23. De Lange, H.J.; Sala, S.; Vighi, M.; Faber, J.H. Ecological vulnerability in risk assessment—a review and perspectives. Sci. Total Environ. 2010, 408, 3871-3879. [CrossRef]

24. McKinney, M.L. Extinction vulnerability and selectivity: Combining ecological and paleontological views. Annu. Rev. Ecol. Syst. 1997, 28, 495-516. [CrossRef]

25. Stella, J.S.; Pratchett, M.S.; Hutchings, P.A.; Jones, G.P. Coral-associated invertebrates: Diversity, ecological importance and vulnerability to disturbance. Oceanogr. Mar. Biol. 2011, 49, 43-104. [CrossRef]

26. Bouzarovski, S. Energy poverty in the European Union: Landscapes of vulnerability. Wiley Interdiscip. Rev. Energy Environ. 2014, 3, 276-289. [CrossRef]

27. Middlemiss, L.; Gillard, R. Fuel poverty from the bottom-up: Characterising household energy vulnerability through the lived experience of the fuel poor. Energy Res. Soc. Sci. 2015, 6, 146-154. [CrossRef]

28. Moser, C.O. The asset vulnerability framework: Reassessing urban poverty reduction strategies. World Dev. 1998, 26, 1-19. [CrossRef]

29. Harvey, C.A.; Rakotobe, Z.L.; Rao, N.S.; Dave, R.; Razafimahatratra, H.; Rabarijohn, R.H.; Rajaofara, H.; MacKinnon, J.L. Extreme vulnerability of smallholder farmers to agricultural risks and climate change in Madagascar. Philos. Trans. R. Soc. B 2014, 369, 20130089. [CrossRef] [PubMed]

30. Luers, A.L.; Lobell, D.B.; Sklar, L.S.; Addams, C.L.; Matson, P.A. A method for quantifying vulnerability, applied to the agricultural system of the Yaqui Valley, Mexico. Glob. Environ. Chang. 2003, 13, 255-267. [CrossRef]

31. Reilly, J.M.; Schimmelpfennig, D. Agricultural impact assessment, vulnerability, and the scope for adaptation. Clim. Chang. 1999, 43, 745-788. [CrossRef]

32. Wang, B.; Ke, R.Y.; Yuan, X.C.; Wei, Y.M. China's regional assessment of renewable energy vulnerability to climate change. Renew. Sustain. Energy Rev. 2014, 40, 185-195. [CrossRef]

33. Gatto, A.; Busato, F. Energy vulnerability around the world: The global energy vulnerability index (GEVI). J. Clean. Prod. 2020, 253, 118691. [CrossRef]

34. Adger, W.N.; Hughes, T.P.; Folke, C.S.R.; Rockstrom, J. Social-ecological resilience to coastal disasters. Science 2005, 309, 1036-1039. [CrossRef]

35. Hahn, M.B.; Riederer, A.M.; Foster, S.O. The Livelihood Vulnerability Index: A pragmatic approach to assessing risks from climate variability and change-A case study in Mozambique. Glob. Environ. Chang. 2009, 19, 74-88. [CrossRef]

36. Poudel, S.; Funakawa, S.; Shinjo, H.; Mishra, B. Understanding households' livelihood vulnerability to climate change in the Lamjung district of Nepal. Environ. Dev. Sustain. 2020, 22, 8159-8182. [CrossRef]

37. Aryal, S.; Cockfield, G.; Maraseni, T.N. Vulnerability of Himalayan transhumant communities to climate change. Clim. Chang. 2014, 125, 193-208. [CrossRef]

38. Bhattacharjee, K.; Behera, B. Determinants of household vulnerability and adaptation to floods: Empirical evidence from the Indian State of West Bengal. Int. J. Disast. Risk Res. 2018, 31, 758-769. [CrossRef]

39. Ashikin, A.N.; Diana, M.N.; Siwar, C.; Alam, M.; Yasar, M. Community Preparation and Vulnerability Indices for Floods in Pahang State of Malaysia. Land 2021, 10, 198. [CrossRef]

40. Nguyen, M.H.; Le, D.P.; Vo, T.T. Vulnerability to Natural Disaster and Welfare Effect: A Case Study of Flood Risk in Vietnam's North Central Region. J. Asian Afr. Stud. 2021, 1, 0021909621993499. [CrossRef] 
41. Nguyen, T.A.; Nguyen, B.T.; Van Ta, H.; Nguyen, N.T.P.; Hoang, H.T.; Nguyen, Q.P.; Hens, L. Livelihood vulnerability to climate change in the mountains of Northern Vietnam: Comparing the Hmong and the Dzao ethnic minority populations. Environ. Dev. Sustain. 2021, 1, 21. [CrossRef]

42. Zhu, R.; Fang, Y.; Neupane, N.; Koirala, S.; Zhang, C. Drought stress and livelihood response based on evidence from the Koshi river basin in Nepal: Modeling and applications. Water 2020, 12, 1610. [CrossRef]

43. Hulssiep, M.; Thaler, T.; Fuchs, S. The influence of humanitarian assistance on post Disaster social vulnerabilities: Early reflection on the nepal earthquake 2015. Disasters 2021, 45, 577-603. [CrossRef]

44. Jaman, T.; Dharanirajan, K.; Sharma, S.S. Assessment of impact of cyclone hazard on social vulnerability of Bhadrak District of Odisha State during Phailin Cyclone in 2013 and Titli Cyclone in 2018 using multi-criteria analysis and geospatial techniques. Int. J. Disast. Risk Reduct. 2021, 53, 101997. [CrossRef]

45. Lee, S.; Ham, Y. Probabilistic framework for assessing the vulnerability of power distribution infrastructures under extreme wind conditions. Sustain. Cities Soc. 2021, 65, 102587. [CrossRef]

46. McIntosh, R.D.; Becker, A. Expert evaluation of open-data indicators of seaport vulnerability to climate and extreme weather impacts for US North Atlantic ports. Ocean Coast. Manag. 2019, 180, 104911. [CrossRef]

47. Eakin, H.C.; Lemos, M.C.; Nelson, D.R. Differentiating capacities as a means to sustainable climate change adaptation. Glob. Environ. Chang. 2014, 27, 1-8. [CrossRef]

48. Guo, S.L.; Li, C.J.; Wei, Y.L.; Zhou, K.; Liu, S.Q.; Xu, D.D.; Li, Q.Y. Impact of land expropriation on farmers' livelihoods in the mountainous and hilly regions of Sichuan, China. J. Mt. Sci. 2019, 16, 2484-2501. [CrossRef]

49. Guo, S.; Lin, L.; Liu, S.; Wei, Y.; Xu, D.; Li, Q.; Su, S. Interactions between sustainable livelihood of rural household and agricultural land transfer in the mountainous and hilly regions of Sichuan, China. Sustain. Dev. 2019, 27, 725-742. [CrossRef]

50. DFID, U.K. Sustainable Livelihoods Guidance Sheets; DFID: London, UK, 1999; p. 445.

51. Rusciano, V.; Civero, G.; Scarpato, D. Social and Ecological High Influential Factors in Community Gardens Innovation: An Empirical Survey in Italy. Sustainability 2020, 12, 4651. [CrossRef]

52. Kuang, F.; Jin, J.; He, R.; Ning, J.; Wan, X. Farmers' livelihood risks, livelihood assets and adaptation strategies in Rugao City, China. J. Environ. Manag. 2020, 264, 110463. [CrossRef]

53. Xu, D.; Deng, X.; Guo, S.; Liu, S. Sensitivity of livelihood strategy to livelihood capital: An empirical investigation using nationally representative survey data from rural China. Soc. Indic. Res. 2019, 144, 113-131. [CrossRef]

54. Yang, H.X.; Huang, K.; Deng, X.; Xu, D.D. Livelihood Capital and Land Transfer of Different Types of Farmers: Evi-dence from Panel Data in Sichuan Province, China. Land 2021, 10, 532. [CrossRef]

55. Zeng, X.Y.; Guo, S.L.; Deng, X.; Xu, D.D. Livelihood risk and adaptation strategies of farmers in earthquake hazard threatened areas: Evidence from Sichuan province, China. Int. J. Disaster Risk Reduct. 2020, 51, 101971. [CrossRef]

56. Zeng, X.; Fu, Z.; Deng, X.; Xu, D. The Impact of Livelihood Risk on Farmers of Different Poverty Types: Based on the Study of Typical Areas in Sichuan Province. Agriculture 2021, 11, 768. [CrossRef]

57. Nguyen, Y.T.B.; Leisz, S.J. Determinants of livelihood vulnerability to climate change: Two minority ethnic communities in the northwest mountainous region of Vietnam. Env. Sci. Policy 2021, 123, 11-20. [CrossRef]

58. Mainali, J.; Pricope, N.G. Mapping the need for adaptation: Assessing drought vulnerability using the livelihood vulnerability index approach in a mid-hill region of Nepal. Clim. Dev. 2019, 11, 607-622. [CrossRef]

59. Barrios, S.; Ouattara, B.; Strobl, E. The impact of climatic change on agricultural production: Is it different for Africa? Food Policy 2008, 33, 287-298. [CrossRef]

60. Ortiz-Bobea, A.; Ault, T.R.; Carrillo, C.M.; Chambers, R.G.; Lobel, D.B. Anthropogenic climate change has slowed global agricultural productivity growth. Nat. Clim. Chang. 2021, 11, 306-312. [CrossRef]

61. Wang, F.T.; Liu, W.Q. A preliminary study on climatic vulnerability of agricultural production in the Loess Plateau. Clim. Environ. Res. 2003, 8, 91-100. (In Chinese)

62. Piya, L.; Joshi, N.P.; Maharjan, K.L. Vulnerability of Chepang households to climate change and extremes in the Mid-Hills of Nepal. Clim. Chang. 2016, 135, 521-537. [CrossRef]

63. Intergovernmental Panel on Climate Change (IPCC). Climate Change 2007: Impacts, Adaptation and Vulnerability: Contribution of Working Group II to the Fourth Assessment Report of the IPCC; Cambridge University Press: Cambridge, UK, 2007.

64. Intergovernmental Panel on Climate Change (IPCC). Climate Change 2014: Impacts, Adaptation, and Vulnerability. Part A: Global and Sectoral Aspects. Contribution of Working Group II to the Fifth Assessment Report; Cambridge University Press: Cambridge, UK, 2014.

65. Gentle, P.; Thwaites, R.; Race, D.; Alexander, K. Differential impacts of climate change on communities in the middle hills region of Nepal. Nat. Hazards 2014, 74, 815-836. [CrossRef]

66. Panthi, J.; Aryal, S.; Dahal, P.; Bhandari, P.; Krakauer, N.Y.; Pandey, V.P. Livelihood vulnerability approach to assessing climate change impacts on mixed agro-livestock smallholders around the Gandaki River Basin in Nepal. Reg. Environ. Chang. 2016, 16, 1121-1132. [CrossRef]

67. Zhou, W.; Guo, S.; Deng, X.; Xu, D. Livelihood resilience and strategies of rural residents of earthquake-threatened areas in Sichuan Province, China. Nat. Hazards 2021, 106, 255-275. [CrossRef]

68. Fussel, H.M.; Klein, R.J.T. Climate Change Vulnerability Assessments: An Evolution of Conceptual Thinking. Clim. Chang. 2006, 75, 301-329. [CrossRef] 
69. Xu, D.; Zhou, W.; Deng, X.; Ma, Z.; Yong, Z.; Qing, C. Information credibility, disaster risk perception and evacuation willingness of rural households in China. Nat. Hazards 2020, 103, 2865-2882. [CrossRef]

70. Xu, D.D.; Qing, C.; Deng, X.; Yong, Z.L.; Zhou, W.F.; Ma, Z.X. Disaster Risk Perception, Sense of Pace, Evacuation Willingness, and Relocation Willingness of Rural Households in Earthquake-Stricken Areas: Evidence from Sichuan Province, China. Int. J. Environ. Res. Public Health 2020, 17, 602. [CrossRef]

71. Xu, D.D.; Zhuang, L.M.; Deng, X.; Qing, C.; Yong, Z.L. Media Exposure, Disaster Experience, and Risk Perception of Rural Households in Earthquake-Stricken Areas: Evidence from Rural China. Int. J. Environ. Res. Public Health 2020, 17, 3246. [CrossRef] [PubMed]

72. Zhuang, L.; He, J.; Yong, Z.; Deng, X.; Xu, D. Disaster information acquisition by residents of China's earthquake-stricken areas. Int. J. Disaster Risk Reduct. 2020, 51, 101908. [CrossRef]

73. Yong, Z.L.; Zhuang, L.M.; Liu, Y.; Deng, X.; Xu, D.D. Differences in the Disaster-Preparedness Behaviors of the General Public and Professionals: Evidence from Sichuan Province, China. Int. J. Environ. Res. Public Health 2020, 17, 5254. [CrossRef]

74. Xu, D.; Yong, Z.; Deng, X.; Liu, Y.; Huang, K.; Zhou, W.; Ma, Z. Financial Preparation, Disaster Experience, and Disaster Risk Perception of Rural Households in Earthquake-Stricken Areas: Evidence from the Wenchuan and Lushan Earthquakes in China's Sichuan Province. Int. J. Environ. Res. Public Health 2019, 16, 3345. [CrossRef]

75. Xu, D.; Guo, S.; Xie, F.; Liu, S.; Cao, S. The impact of rural laborer migration and household structure on household land use arrangements in mountainous areas of Sichuan Province, China. Habitat Int. 2017, 70, 72-80. [CrossRef]

76. Yohe, G.; Tol, R.S. Indicators for social and economic coping capacity-moving toward a working definition of adaptive capacity. Glob. Environ. Chang. 2002, 12, 25-40. [CrossRef]

77. Debortoli, N.S.; Camarinha, P.; Marengo, J.A.; Rodrigues, R.R. An index of brazil's vulnerability to expected increases in natural flash flooding and landslide disasters in the context of climate change. Nat. Hazards 2017, 86, 557-582. [CrossRef]

78. Peng, L.; Xu, D.; Wang, X. Vulnerability of rural household livelihood to climate variability and adaptive strategies in landslidethreatened western mountainous regions of the Three Gorges Reservoir Area, China. Clim. Dev. 2019, 11, 469-484. [CrossRef]

79. Lim, S.J.; Park, H.J.; Kim, H.S.; Park, S.I.; Han, S.S.; Kim, H.J.; Lee, S.H. Vulnerability assessment of forest landslide risk using GIS adaptation to climate change. For. Sci. Technol. 2016, 12, 207-213. [CrossRef]

80. Hoq, M.S.; Raha, S.K.; Hossain, M.I. Livelihood vulnerability to flood hazard: Understanding from the flood-prone Haor Ecosystem of Bangladesh. Environ. Manag. 2021, 67, 532-552. [CrossRef]

81. Xu, D.; Liu, E.; Wang, X.; Tang, H.; Liu, S. Rural Households' Livelihood Capital, Risk Perception, and Willingness to Purchase Earthquake Disaster Insurance: Evidence from Southwestern China. Int. J. Environ. Res. Public Health 2018, 15, 1319. [CrossRef]

82. Zeng, G.A.; Yang, P.H. The impact of natural disasters on the income gap among households in China: A study based on CFPS (2014) survey data. Fujian Forum 2018, 5, 5-16. (In Chinese)

83. Mottaleb, K.A.; Mohanty, S.; Hoang, H.T.K.; Rejesus, R.M. The effects of natural disasters on farm household income and expenditures: A study on rice farmers in Bangladesh. Agric. Syst. 2013, 121, 43-52. [CrossRef]

84. Wu, X.H.; Guo, J. Study on Impact Assessment of Meteorological Disaster on Industrial Economic System. In Proceedings of the Sixth Forum on Rain, Snow and Frost Disaster in Shenyang; Chinese Meteorological Society, Beijing, China, 12 September 2012; p. 13. (In Chinese)

85. Iqbal, M.A.; Rizwan, M.; Abbas, A.; Makhdum, M.S.A.; Kousar, R.; Nazam, M.; Samie, A.; Nadeem, N.A. Quest for Livelihood Sustainability? Patterns, Motives and Determinants of Non-Farm Income Diversification among Agricultural Households in Punjab Pakistan. Sustainability 2021, 13, 9084. [CrossRef]

86. Carpenter, S.; Walker, B.; Anderies, J.M.; Abel, N. From metaphor to measurement: Resilience of what to what? Ecosystems 2001, 4, 765-781. [CrossRef]

87. Adger, W.N.; Kelly, P.M. Social Vulnerability to Climate Change and the Architecture of Entitlements. Mitig. Adapt. Strateg. Glob. Chang. 1999, 4, 253-266. [CrossRef]

88. Liu, Y.; Zhao, M.; Liu, D. Exposure, sensitivity, and social adaptive capacity related to climate change: Empirical research in China. Chin. J. Popul. Resour. Environ. 2017, 15, 209-219. [CrossRef]

89. Iglesias, A. Climate change and agriculture: An economic analysis of global impacts, adaptation and distributional effects. Eur. Rev. Agric. Econ. 2010, 37, 421-423. [CrossRef]

90. Yang, L.; Liu, M.C.; Min, Q.W. Natural Disasters, Public Policies, Family Characteristics, or Livelihood Assets? The Driving Factors of Farmers' Livelihood Strategy Choices in a Nature Reserve. Sustainability 2019, 11, 5423. [CrossRef]

91. Alam, G.M. Livelihood cycle and vulnerability of rural households to climate change and hazards in Bangladesh. Environ. Manag. 2017, 59, 777-791. [CrossRef]

92. Sarker, M.N.I.; Wu, M.; Alam, G.M.; Shouse, R.C. Livelihood vulnerability of riverine-island dwellers in the face of natural disasters in Bangladesh. Sustainability 2019, 11, 1623. [CrossRef]

93. Sujakhu, N.M.; Ranjitkar, S.; He, J.; Schmidt-Vogt, D.; Su, Y.; Xu, J. Assessing the livelihood vulnerability of rural indigenous households to climate changes in Central Nepal, Himalaya. Sustainability 2019, 11, 2977. [CrossRef]

94. Malakar, K.; Mishra, T.; Patwardhan, A. Perceptions of multi-stresses impacting livelihoods of marine fishermen. Mar. Policy 2018, 97, 18-26. [CrossRef]

95. Pandey, R.; Jha, S.K.; Alatalo, J.M.; Archie, K.M.; Gupta, A.K. Sustainable livelihood framework-based indicators for assessing climate change vulnerability and adaptation for Himalayan communities. Ecol. Indic. 2017, 79, 338-346. [CrossRef] 
96. Zhao, X.Y.; Jie, Y.Q.; He, Y.Q.; He, X.F.; Mu, F.F.; Su, H.Z.; Lan, H.X. Livelihood adaptability of farmers in key ecological function areas under multiple pressures: A case study of the Yellow River water supply area in Gannan. Popul. Res. Environ. 2020, 30, 140-149. (In Chinese)

97. Thulstrup, A.W. Livelihood resilience and adaptive capacity: Tracing changes in household access to capital in Central Vietnam. World Dev. 2015, 74, 352-362. [CrossRef]

98. Liu, W.; Li, J.; Ren, L.; Xu, J.; Li, C.; Li, S. Exploring livelihood resilience and its impact on livelihood strategy in rural China. Soc. Indic. Res. 2020, 150, 977-998. [CrossRef]

99. Azam, G.; Huda, M.E.; Bhuiyan, M.A.H.; Mohinuzzaman, M.; Bodrud-Doza, M.; Islam, S.D.U. Climate Change and Natural Hazards Vulnerability of Char Land (Bar Land) Communities of Bangladesh: Application of the Livelihood Vulnerability Index (LVI). Glob. Soc. Welfare 2019, 1, 13. [CrossRef]

100. Gerlitz, J.Y.; Macchi, M.; Brooks, N.; Pandey, R.; Banerjee, S.; Jha, S.K. The multidimensional livelihood vulnerability index-an instrument to measure livelihood vulnerability to change in the Hindu Kush Himalayas. Clim. Dev. 2017, 9, 124-140. [CrossRef]

101. Shah, K.U.; Dulal, H.B. Household capacity to adapt to climate change and implications for food security in Trinidad and Tobago. Reg. Environ. Chang. 2015, 15, 1379-1391. [CrossRef]

102. Li, Y.; Wang, Y. Study on multidimensional Poverty Decomposition of Farmers with different livelihood strategies in western China. J. Xi'an Univ. Financ. Econ. 2021, 2, 73-80. (In Chinese)

103. Zhou, Y.; Wang, H.L.; Liu, Z.H. Research on the influencing factors of non-agricultural employment of rural households relocated to inhospitable areas under the framework of livelihood resilience: Based on the investigation of Kizilsu Kirgiz Autonomous Prefecture in Xinjiang. Arid Land Resour. Environ. 2020, 11, 29-35. (In Chinese)

104. Ghimire, Y.N.; Shivakoti, G.P.; Perret, S.R. Household-level vulnerability to drought in hill agriculture of Nepal: Implications for adaptation planning. Int. J. Sustain. Dev. World Ecol. 2010, 17, 225-230. [CrossRef]

105. Cattivelli, V.; Rusciano, V. Social Innovation and Food Provisioning during COVID-19: The Case of Urban-Rural Initiatives in the Province of Naples. Sustainability 2020, 12, 4444. [CrossRef]

106. Cisco, G.; Gatto, A. Climate Justice in an Intergenerational Sustainability Framework: A Stochastic OLG Model. Economies 2021, 9, 47. [CrossRef] 